retary, Mr. Smuts; Attorney-General and Minister of Mines, Mr. J. de Villiers; Treasurer, Mr. Hull; Minister of Lands and Native Affairs Mr. Rissik; Minister of Public Works, Mr. E. Solomon.

The composition of the cabinet is regarded as very strong, as it contains the four most influential leaders of the Boer party. General Beyers is speaker of the assembly, and General Schalkburger a prominent member. The fact that within so short a period after the war, the leaders of the vanquished have been permitted to get political power and authority into their hands, is universally commented on as a most striking instance of the traditional liberalism of British colonial policy. General Botha will take part, as one of the colonial premiers, in the colonial conference at London. The first measure introduced by the new government is the Asiatic ordinance, which aims at the exclusion of other Indian and other Asiatic immigrants of the small trading class. This act was passed by the late legislative assembly, but was disallowed at that time by the colonial secretary. The ordinance is causing some uneasiness in India and Japan.

\title{
INTERNATIONAL RELATIONS
}

\section{PAUL S. REINSCH}

On January twenty-fourth, the ambassadors of France and of Italy at Constantinople sent a joint note to the Porte which announced that certain religious establishments belonging to the Dominican and Franciscan missions in Asia Minor, which had hitherto been under the French religious protectorate, would hereafter be under Italian protection. This arrangement indicates the desire of a large number of the Roman Catholic ecclesiastics working in the near East to leave the protection of France. The historic position of France as the protector of Christian missions in the Orient appears, therefore, more seriously threatened than ever before, on account of the controversy between the French government and the Vatican.

The question of patent and trade-mark protection in China has not as yet been satisfactorily settled. At present there is no Chinese law on the subject, but by mutual agreement the leading nations of Europe and the United States have arranged that their citizens shall enjoy the same protection of these rights in China which they are guaranteed by the general treaties between these powers. Japan is 
not a party to these arrangements, and it is reported that Japanese tradesmen in China have made rather unscrupulous use of this freedom from legal limitations in using the trade-marks of other nations. Several years ago the Chinese government had worked out a law for the protection of trade-marks. This project, however, was unsatisfactory to the powers, because of the high fees to be charged under it, and because it was so worded that it would have interfered with the consular jurisdiction of the powers. The ministry of agriculture, commerce, and industry has recently submitted a new project to the Wai-wu-pu, in which these objectionable features have been avoided. European and American merchants consider the adoption of such a law of great importance.

The central government of China, in January, issued orders to the governors of the principal opium-raising provinces to the effect that the area devoted to the culture of opium is to be reduced by one-tenth its former extent this year. The British ambassador at Peking has been engaged in negotiations with the government concerning the Indian opium trade. It is currently reported that an agreement was reached in February, according to which the importation of Indian opium into China is to be reduced in the same ratio as the native production.

The situation in Manchuria is still far from settled. While the withdrawal of the troops, with the exception of the railway guards, has been practically completed, the relations between the Chinese administration, on the one hand, and the Japanese and Russian authorities, on the other, have not been adjusted in any satisfactory manner. The questions of special difficulty in southern Manchuria are connected with the attempts of the Chinese officials to impose transit duties on internal trade, their desire to limit the residence and business activities of foreigners strictly to fixed settlements adjoining the treaty ports, the delimitation of the latter areas, and the adjustment of controversies with respect to leases and other real property rights acquired by the Japanese. The governor of Kiriñ, for instance, has attempted to enforce regulations providing that the settlements of foreigners shall be without the town, that all foreign business shall be carried on in these settlements, and that the Chinese local authorities shall not be interfered with in the treaty ports. The Japanese authorities and representatives have been busily engaged in 
fixing the boundaries of station areas along the railway, which they control under the treaty, as well as of the Japanese settlements adjoining the treaty ports. The northern boundaries of the Kwantung territory (the southern portion of Liao-tung peninsula) have been determined; during the period of the Russian lease they had been left indeterminate. The evacuation of northern Manchuria by the Russian troops has also nearly been accomplished. The Japanese government has appointed a consul-general for Harbin and a consul for Kiriñ, and it is not believed that the Russian government will oppose any effectual resistance to the opening of the North Manchurian treaty ports. The relations between the Russian and the Chinese authorities are in a similarly unsettled condition as those described in respect to southern Manchuria.

The negotiations between Japan and Russia, relative to the application of certain dispositions of the treaty of Portsmouth and to other purposes, have not yet come to a satisfactory conclusion. The main points waiting to be settled in these negotiations are the following: The commercial rights of the subjects of one power in the territory of the other; the navigation of rivers; the creation of consulates in Oriental Russia; the question of passports; and, especially, the question of fisheries. A special Russo-Japanese commission has been appointed to determine the exact meaning of the words "inlet," and "anse," which are employed, respectively, in the English and French texts of the Portsmouth protocols. The question particularly involved is that of the size of an inlet. According to recent reports the suggestion has been made that the effort to determine the question on the principle of size should be abandoned and a compromise should be attempted by determining upon certain inlets as open to Japanese fishermen.

During the first five months subsequent to the issue of the Korean mining regulations, about one-fifth of the two hundred applications for mining concessions were disposed of. Some of the most valuable mining privileges have been granted to British, German, American, and French subjects, but the larger number of concessionaires are Korean and Japanese.

The question of the admission of Japanese laborers has been temporarily adjusted by orders of the president, prohibiting the immigration of such laborers from Hawaii, Canada, or Mexico. The Japa- 
nese government has for some time past made it a practice not to issue any passports to laborers desiring to come directly to the United States. Such immigration as has taken place was, therefore, roundabout, through our insular possessions or neighboring countries. The American government relies upon the continuation of this practice by the Japanese government and hopes to make a more permanent settlement of the matter by treaty. The president was empowered by act of congress to issue an exclusion order, in the following terms: "That whenever the president shall be satisfied that passports issued by any foreign government to its citizens to go to any country other than the United States, or to any insular possessions of the United States or to the canal zone, are being used for the purpose of enabling the holders to come to the continental territory of the United States, to the detriment of labor conditions therein, the president may refuse to permit such citizens of the country issuing such passports to enter the continental territory of the United States from such other countries, or from such insular possessions, or from the canal zone." On the basis of this legislative authorization, the president on March 14 issued an executive order in which he recites that evidence has been produced by the department of commerce and labor, which establishes that passports issued by Japan to laborers to go to Mexico, Canada, and Hawaii are being used for the purpose of enabling their holders to come to continental territory of the United States "to the detriment of labor conditions therein." The main part of the order reads: "I hereby order that such eitizens of Japan or Corea, to wit: Japanese or Corean laborers, skilled and unskilled, who have received passports to go to Mexico, Canada, or Hawaii, and come therefrom, be refused permission to enter the continental territory of the United States."

The question of school rights of Japanese children which gave rise to the more general question of exclusion, was settled by prevailing upon the San Francisco school board to admit Japanese children under certain conditions as to age and the ability to use the English language. Upon special insistence of the president, the legislature of California decided to take no action on certain bills and resolutions unfavorable to the Japanese. The fact that a school board, city officials at the time under indictment, and a State legislature had to be taken into council by the president in arranging a matter of 
foreign policy impressed foreign observers with the complexity of our institutions. During the course of the controversy, the president had ordered actions to be brought to test the right of Japanese children to gain admission to the schools. These actions were later discontinued when a settlement had been reached.

The preliminary discussion of the program of the second Hague conference has revealed a great difference of opinion among nations as to the advisability of discussing the joint limitation of military expenditure. The British government is strongly in favor of including this subject in the program; the British prime minister has even made an appeal to public opinion, through an article in the new liberal paper, The Nation, in which he dwells upon the established pacific and commercial policy of Great Britain and the groundlessness of all suspicions against her. The principal continental nations are not, however, inclined to look upon the matter in this way. Considering the vast handicap under which they suffer when confronted with the British naval establishment, they seem to feel that a policy of making the present ratio of expenditure permanent would give Great Britain a permanent and increasing advantage. In the tentative program submitted by Russia to the European chancelleries, the question of limitation of armament is not referred to. On account of the policy of Great Britain to surround Germany with hostile alliances on all sides the latter power is unwilling to fall in with the British plan, nor does the idea find favor even in France. At present the annual naval expenditure of Great Britain is about two and one-half times as large as that of either France or Germany and three times as large as that of Russia. It is not considered likely, therefore, that the subject will be included in the official program. A more specific discussion and determination of the laws of war appears to have a better chance of realization.

A recent decision by Judge Ewing in the United States circuit court at Pittsburg to the effect that a nonresident alien is not entitled to the benefit of a statute giving a right of action for death of another by wrongful act calls attention to the abnormal status which such suitors occupy in some states.

The general rule is that statutes are presumed to have no extraterritorial force. (Endlich: Interpretation of Statutes, \$169.) Neither in Lord Campbell's act, nor in the various State statutes creating a 
cause of action for death by wrongful act is there any express provision that the action may be maintained by a nonresidert alien. The English courts have held that the provisions of Lord Campbell's act by which damages can be recovered for death caused by negligence do not apply for the benefit of aliens abroad; that it is a principle of English law that acts of Parliament do not apply to nonresident aliens unless the language of the statute expressly refers to them; that the power of the country is to legislate for its own subjects all over the world, and as to foreigners within its jurisdiction, but no further. Adam v. British and Foreign S. S. Co. (1898) 2 Q. B. 430 . To the same effect are Deni v. Pennsylvania R. Co. 181 Pa. 525; Brannigan v. Union Gold-Min. Co. 93 Fed. 164 (U. S. Cir. Ct. Col.); MeMillan v. Spider Lake S. \& L. Co. (Wis. 1902) 60 L. R. A. 589.

In Mulhall v. Fallon, 176 Mass. 266, it is conceded that legislative power is territorial, and that no duties can be imposed by statute upon persons who are within the limits of another State, but it is held that rights can be offered to such persons, and if the power that governs them makes no objection, there is nothing to hinder their accepting what is offered; and accordingly that a nonresident alien may sue under a statute giving damages for death from negligence. Commenting on the English case cited above, it is said: "Our different relation to our neighbors, politically and territorially, is a sufficient ground for a more liberal rule." To the same effect are Kellyville Coal Co. v. Petraytis, 195 Ill. 215; Vetaloro v. Perkins 101 Fed. 393 (U. S. Cir. Ct. Mass. 1900); Bonthron v. Phoenix Light \& F. Co. (Ariz. 1903) 61 L.R.A. 563. See in general 54 L.R.A. 934, note.

Count Lamsdorf, Russian minister for foreign affairs from 1900 to 1903, died at San Remo on March 19. He entered the public service in the foreign office in 1866 and remained there continuously until 1903. His career is an illustration of the continuity of diplomatic experience in Russia, and it calls to mind the fact that Russia had only five ministers of foreign affairs during the period from 1815 to 1900.

The thirteenth annual Lake Mohonk Conference on International Arbitration will be held on May 22-24. President Nicholas Murray Butler will act as presiding officer. In the discussions, special stress is to be laid on Pan-American interest in international arbitration. 
The first annual meeting of the American Society of International Law was held at Washington, D. C., April 19 and 20. The program comprised papers and discussion on the following topics:

1. Would immunity from capture during war of non-offending private property upon the high seas be in the interest of civilization?

2 . Is the trade in contraband of war unneutral and should it be prohibited by international and municipal law?

3. Transference from municipal courts to an international court of all prize cases.

4. Is the forcible collection of contract debts in the interest of international justice and peace?

5. The rights of foreigners in the United States in case of conflict between federal treaties and State laws.

6. The second Hague conference and the development of international law as a science.

The representatives of the European powers in Morocco have presented two joint notes to the Maghzen in which they insist on the necessity of restoring order at Mogador, and protest because certain reforms called for by the Algeciras act have not been put into effect. The chief clauses involved deal with coastwise trade, cattle export, and the purchase of land by foreigners. Notwithstanding the poor financial condition of the country, several large contracts for harbor works have been made with French and German construction companies. Internal intrigues and general insecurity continue. French troops, in March, occupied Oudja near the Algerian frontier, on the claim that the security of the region demanded such action.

Though Anglo-Russian relations in Persia have not as yet been made the subject of a formal treaty, it is reported that an understanding has been arrived at, according to which these two powers will observe a policy of strict neutrality and non-intervention in the internal affairs of that country. Nevertheless, in March, serious disorders at Sebzewar in northern Khorassan threatening the lives of resident Russian subjects, Russian troops were set in motion to restore security.

The fact that Canada, though still formally a ward of Great Britain, is taking an important position in the family of nations, has recently been attested by the visit of Secretary Root to the Dominion, as well as by the conferences between the British ambassador, Mr. James Bryce, and the Canadian government. Among the diplomatic ques- 
tions pending between Canada and the United States, to the solution of which the above meetings are expected to contribute in no small degree, are the following: Commercial reciprocity and transit of merchandise, Niagara Falls preservation and water rights, seal protection and fisheries, application of alien labor laws, and complete determination of boundary lines.

The United States senate adopted the following resolution, February 15:

Whereas, It is alleged that the native inhabitants of the basin of the Congo have been subjected to inhuman treatment of a character that should claim the attention and excite the compassion of the people of the United States; therefore, be it

Resolved, That the president is respectfully advised that, in case he shall find such allegations are established by proof, he will receive the cordial support of the senate in any steps, not inconsistent with treaty or other international obligations or with the traditional American foreign policy which forbids participation by the United States in the settlement of political questions which are entirely European in their scope, he may deem it wise to take in coöperation with or in aid of any of the powers signatory of the treaty of Berlin for the amelioration of the condition of such inhabitants. 